of revision of philosophical fundamentals of domestic jurisprudence, its departure from the positions of methodological monism, the introduction of new values, and the provision of legal science with the needs of the development of the economic system of Ukraine in the process of its transition to market principles. However, despite the declaration of the importance of methodological issues, this period as a whole is characterized by the lack of its integrated development. It is established that the given situation is connected with the fact that the periods of fundamental transformations of the fundamentals of science under the necessity do not contribute to a thorough research of methodological issues, since at this stage of development of knowledge the first questions arise the search for new ideological, value and ideological guidelines, the formation of the foundations of science.

Key words: methodology, legal research, methodological pluralism, basis of science.

DOI: 10.33.66.3/2524-017X-2019-10-128-132

УДК 340

\author{
Світлана Евгенівна Камаралі, \\ дочент кафедри теорії, історії права і держави \\ та конституиійного права Університету державноі \\ фіскальної служби України, кандидат історичних наук, дочент
}

Дмитро Анатолійович Шевченко,

заступник начальника відділу поліції з обслуговування житлового масиву «Виноградар» Подільського управління полічї ГУНП в м. Києві, кандидат юридичних наук

\title{
ТОРГОВЕЛЬНА ПОЛІТИКА УРЯДУ ПАВЛА СКОРОПАДСЬКОГО: ІСТОРИКО-ПРАВОВИЙ МОНІТОРИНГ
}

Постановка проблеми. В умовах докорінного реформування українського суспільства перед Україною постала низка завдань, у першу чергу, економічних, при вирішенні яких необхідно спиратись як на світовий, так і на вітчизняний досвід. Дослідженння організаційно-правових основ фінансово-економічної діяльності в часи перебування Української Держави актуальне для подолання проблем становлення національної економіки, торгівлі, побудови тривкої фінансової системи. Їх творче використання може стати ефективним при виробленні засад сучасної господарчої політики.

Мета статті. Метою статті є аналіз організаційно-правових основ діяльності уряду гетьмана П. Скоропадського в галузі внутрішньої торгівлі; визначення пріоритетних векторів фінансово-економічної політики в період кризи державотворення.

Аналіз останніх досліджень та публікацій. Сучасний стан досліджень цієї проблематики окреслено в працях І. Бойка, П. Гая-Нижника, Я. Грицака, Т. Гунчака, О. А. Коцура, О. Красівського, М. Кугутяка, В. Кульчицького, Р. Матейка, В. Піскуна, О. Реєнта, Б. Савчука, М. Сеньківа, О. Субтельного, М. Творидла, І. Терлюка, Б. Тищика, Ю. Тлущака та ін.

Основні результати дослідження. Основним зв'язком між сферами виробництва і споживання, грунтовною підвалиною всякого економічного будівництва виступає торгівля. Перша світова війна істотно вплинула на їі розвиток. Через переведення багатьох підприємств на військові замовлення торгові зв'язки руйнувалися. Внутрішня торгівля приймала все більше натуралізований характер обміну. Ярмаркова діяльність поступово згасала. А постійні розподіли українських земель між військовими сторонами виключали будь-яку можливість торговельних зв'язків. Після розпаду Російської імперії економічні стосунки між ії регіонами були розірвані. Отримали розповсюдження базари, де розквітла спекуляція. Внаслідок інфляції гроші втратили довіру, перевага віддавалася обміну товарами. Біржі припинили своє існування. Через нестачу харчових продуктів, різкого зниження покупної спроможності населення магазини, ресторани збанкрутіли, а інші були пограбовані за часи революційних подій.

Гетьманському уряду у спадщину залишилася скинута майже до феодального рівня торгівля. Спираючись на підприємців і торговельників, гетьман П. Скоропадський поновив приватну влас- 
ність і в «Грамоті до всього українського народу» пообіцяв усім підприємцям повну свободу торгівлі й відкриття широкого простору приватному підприємництву. Але міністр шляхів сполучень Б. Бутенко на з’їзді «Партії Народної Свободи на Україні» 9 травня 1918 р. окреслив протекціоністські напрями державної політики: «Необхідно рахуватись 3 тим, що державі доведеться удатись до ряду монополій й нормування, як з метою створення державних фінансів, так і для задоволення потреб широких мас населення в предметах першої необхідності» [7].

Економічну ситуацію ускладнювала залежність Української держави від торгових зобов'язань Брест-Литовського договору із Німеччиною та Австро-Угорщиною, виконання економічних зобов'язань відносно Центральних Держав виступало гарантом існування самостійної України. 3 огляду на важливість і необхідність негайного вирішення питань торговельної галузі, при Міністерстві торгу і промисловості замість «Державної Комісії по товарообміну», заснованої Центральною Радою, було утворено «Відділ для виготовлення торгово-економічних договорів» при Департаменті закордонної торгівлі. Крім цього, з ініціативи громадських і торговельно-промислових організацій було створено Окрему Раду, з допоміжними функціями. Вона займалась вивченням торговельних питань і вела спільну працю з Відділом. Згодом уряд сформував коаліційний «Комітет для зовнішньої торгівлі», перетворений у «Торгову Раду». До ï складу увійшли представники уряду, торгово-промислових сфер, а також Центральних держав. «Торгова Рада» займалась питаннями імпорту та експорту, а також внутрішньої торгівлі.

В рамках зазначеної політики, гетьманський уряд запровадив монополії. Перш за все, цукрової, як фундаменту забезпечення фінансової системи держави. Другою стала монополія на зернові, наступною - горілчана. 3 часом державна монополія поширилась на вироби важкої промисловості. Для проведення організаційної роботи з питання монополії на засіданні Ради Міністрів 3 травня 1918 р. було вирішено скласти відповідні комісії [2].

3 запровадженням монополії на цукор гетьман затвердив «Закон про підвищення постійних цін і продажних монопольних цін на цукор» [8]. Встановлювались нові продажні ціни на цукор-пісок у розмірі від 37 крб 20 коп до 60 крб. за пуд і на рафінад - від 40 крб до 80 крб за пуд, із черговим збільшенням цін 26 червня [12] та 3 вересня 1918 р. [14]. Статистико-економічний відділ Центрального бюро, який відав справами цукрової галузі, утворений за часи Центральної Ради, було реформовано. 17 травня у складі міністерства продовольчих справ з відділів «Центроцукор», «Засівплоща» та відділу «Поставки» було створено нову установу - «Комісія з справ цукру» [9].3 метою підтримки галузі 30 травня 1918 р. було видано закон про фінансування іiї шляхом короткотермінових позичок [4]. На обробку плантацій та реалізацію врожаю 1918 р. власникам і арендаторам цукроварень виділялись значні кошти. Міністерству продовольчих справ на цукрові справи відкривався кредит в сумі 285 млн крб, в рахунок кошторису цукрової монополії. Ці кошти були спрямовані на виплату боргів до затвердження кошторису на впровадження цукрової монополії в 1918 p. [3]. Того ж дня міністру землеробства відкривався кредит в 700 тис. крб на купівлю елітного насіння цукрового буряку та на видачу субсидій селекційним станціям та насіньовим господарствам [11]. Ці заходи мали забезпечити стабільний розвиток цукрової компанії.

Турбуючись про лад і спокій серед підприємців, український уряд вживав не тільки економічні засоби відбудови галузі, а й виступав арбітром у вирішенні суперечок стосовно власності на врожаї. Саме таким засобом став закон, виданий 14 червня 1918 р. в доповнення до закону від 27 травня «Про право на врожай на території Української Держави» [10]. Згідно з законом врожай буряків, посіяних на власній чи арендованій землі цукрових заводів, віднині належав їм, незалежно від того, на яких засадах ці дії були проведені. 3 монополізацією галузі, торгівля цукровими виробами була можлива лише в межах державних норм. Основними торговими партнерами виступали: держава і підприємства.

Враховуючи виключне становище, деяким підприємствам, собівартість цукру яких перевищувала норми, призначалась урядова компенсація. До 1 вересня 1918 р. клопотання про таку допомогу поступили від 8 цукрових заводів [22]. На засіданні Міністерства фінансів під головуванням міністра В. Матусевича 2 жовтня 1918 р. були розглянуті законопроекти, які регулювали взаємовідносини в межах монопольної торгівлі цукром між державою і підприємцями. 14 жовтня Рада Міністрів затвердила закон про деякі зміни та доповнення існуючих законів про продаж цукру у відповідності з проектами [15]. А 16 жовтня гетьман ствердив закон про використання врожаю цукрових буряків біжучого 1918 р. й про відповідальність за порушення цього закону [16]. 
Особливу увагу уряд приділяє галузі, безпосередньо пов'язаній з цукровою промисловістю горілчаній. Ї̈̈ розвиток мав велике значення і в справі відбудови національної фінансової системи. На той час горілчані продукти виступали своєрідною «натуральною валютою» внутрішнього і зовнішнього ринків. Міністерство фінансів склало план відродження винокурної промисловості i торгівлі горілчаними напоями. Робота почалась із затвердження 9 травня 1918 р. гетьманом закону «Про дозвіл винокуріння з кормової патоки» [8]. Завдання українського уряду було в тому, щоб поставити збут спирту в належні рамки. Кабінет Міністрів постановив відновити державну монополію, вважаючи, що цим, з одного боку, буде покладено кінець великому злу - підпільному винокуренню, яке прийняло жахливі розміри, а з другого, в значній мірі збільшити прибутки держави від продажу. Розуміючи важливість відродження горілчаної промисловості, як для фінансової системи, так і для національної торгівлі, уряд вдався до термінових дій.

Щоб організувати винокурну справу, на допомогу уряду прийшли самі підприємці та торговельники, які скликали 30 травня 1918 р. в Києві з'їзд керівників акцизних зборів. Визнавалась необхідність та був схвалений план організації горілчаної монополії [17]. Але промисловці виказали занепокоєність тим, що покриття державних витрат вирішується «п”яним бюджетом». За їхньою ініціативою встановлювались норми споживання горілки. В довершення роботи підприємців, було створено «Товариство винокуренних заводчиків» (далі - «ТВ3») [18]. На підставі волі підприємців 31 липня гетьман затвердив закон про відновлення горілчаної монополії [26]. Відповідальним за проведення цього закону призначався міністр фінансів А. Ржепецький. Віднині для внутрішнього вжитку дозволялось виробництво не більше 4 млн. відер скарбового вина. Торгівля почалась 3 ціни на 1 пляшку у розмірі 100-120 крб. А норма вжитку складала 1 пляшку на місяць на чоловіка. 3 прибутку в 600 млн крб, який могли дати 8-10 млн відер, максимум 400 млн крб поступало у розпорядження міністерства фінансів. Решта використовувалась у культурно-просвітницькі галузі. Однак після поступу у продаж горілчаних виробів за державними цінами вони з'являлись на «чорному ринку» і дрібних шинках за цінами у 3-5 разів вищими. Міністерство фінансів терміново виробляло проект необхідних змін «Статуту про скарбовий продаж напоїв», з метою захисту населення від зловживання міцними напоями і покарання за спекуляцію.

Показники виробництва винокурення і торгівлі їх виробами залишалися досить низькими. «ТВ3» у повному контакті та згоді з Департаментом акцизних зборів, на який було фактично покладено здійснення скарбового продажу, почало діяльність відбудови для вирішення горілчаного дефіциту. Результатом двохмісячної напруженої праці з'явилось пробудження до життя більше 70 заводів. Правління «ТВ3» скрізь зустрічало готовність до співпраці, проте в практичному здійсненні своїх насущних потреб натикалося на бюрократичні складнощі. Відновити показники товарообігу у горілчаній промисловості довоєнного рівня уряду так і не вдалось. Ускладнювалась економічна ситуація і втручаннями з боку німців. Досить часто, не зважаючи на потреби у сировині українських горілчаних заводів, німецьке командування реквізувало чорну патоку, хоч вона і була оголошена власністю Української Держави.

У зв'язку з новими політичними і економічними умовами, i заради відновлення колишніх показників хлібного виробництва і торгівлі 30 травня 1918 р. у Міністра торгу і промисловості відбулась нарада за участю делегації від Київської Продовольчої Управи [17]. Делегація ставила за мету з'ясування меж, повернутої «Грамотою до всього українського народу» вільної торгівлі відносно хлібних продуктів. Міністр торгу і промисловості, від імені уряду, підтвердив закон 27 травня «Про права на врожай 19I8 року на території Української Держави». Він ознайомив присутніх 3 «Наказом в справі хибного розуміння вільної торгівлі хлібом, та в справі твердих цін на хліб». Міністр торгу і промисловості зазначив, що така ситуація виникла «злим надлишком осіб, які зацікавлені в спекулятивному підвищенні цін на хліб» (1 пуд борошна у вільному продажу коштував 80 крб) [24]. I запевнив делегацію, що уряд буде твердо проводити в життя нормування споживання хліба і регулювання торгу до того моменту, коли встановляться нормальні умови економічного життя краю. Значення «Наказу...» було величезним для з'ясування торгових відносин і припинення спекуляційного буму на хліб. До того часу на території України діяли, встановлені 27 серпня 1917 р. тверді ціни на зернові культури. В середньому від 4 карб. 7 коп. - 5 карб. за пуд і на крупи від 3 карб. 3 коп. до 8 карб. за пуд [25].

31 липня Міністерством продовольчих справ було видано «Наказ про тверді ціни на збіжжя та зерновий фураж при переведенні хліба врожаю 1918 року в розпорядження Держави» [19], 
які підвищувались у півтори рази [12]. Встановлення твердих цін на хлібні продукти мало позитивне значення і передбачало перспективний розвиток. Уряд планував поступове зниження їх з грудня 1918 р. на 25\%, а з травня наступного року іще на $25 \%$. Цією системою поступового зниження досягалось забезпечення населення міст, фабричних робітників, а також службовців залізниць хлібом за доступними цінами. Для проведенням «хлібної кампанії» було утворено Державне Хлібне Бюро (далі - Бюро). За Статутом, затвердженим гетьманом П. Скоропадським 17 липня 1918 p. [5], Бюро виступало головним торговим посередником між державою і власниками. Воно повинно було виконувати доручення Міністерства продовольства по справах заготовки, переробки, перевезень, експорту та імпорту хлібних продуктів. Згідно з законом, ніхто, крім Бюро та його членів, 3 моменту оприлюднення, не мав права займатись скупкою хліба на території України, а також перевезенням та перемолом зерна для комерційних цілей. Бюро складалось 3 членів хлібно-біржевого товариства, кооперативів, власників та орендарів торговельних млинів та круподерень. зацікавлених в хлібних справах професіоналів. Через те, що Бюро надавались права юридичної особи, порушення іiі Статуту каралося, якщо не карним чи цивільним судом, то за постановою губерніальних старост - штрафом до 10 тис. крб, або арештом строком до 6-ти місяців. Закон про хлібну монополію, який віддавав весь посів того року в розпоядження держави, і поряд виданий закон про Державне Хлібне Бюро, давали уряду можливість здійснити необхідні міри для розподілення хліба між різними групами населення, виконувати зобов'язання відносно союзних держав.

Поряд із торговою діяльністю Бюро проводило статистичні дослідження і регулярно подавало звіти про становище до Міністерства продовольчих справ. Засновуючись на даних звітів, в доповнення до Закону від 31 липня 1918 р. новий Міністр продовольчих справ С. Гербель встановив 31 серпня наступні граничні ціни за переробку одного пуда зерна в борошно та крупу - 380 коп. до 1 крб 17 коп. [20]. Встановлення твердих цін на зерно і розцінок на усі виробничі операції позитивно відбилося на стані внутрішнього ринку. I хоча торгові операції проходили під контролем держави, після «мертвого» періоду почалося поступове пожвавлення.

Назустріч економічним нововведенням уряду, для координації своїх дій в серпні в Києві зустрілось біля 200 сільськогосподарських підприємців та торговельників на 1-му Всеукраїнському з'їзді мукомолів [20]. 3'їзд гаряче привітав гетьмана та палко обговорював проблеми харчової справи. За ініціативою делегатів було створено Особливий Торговельно-Фінансовий відділ при Раді мукомолів. Він повинен був займатись посильним фінансуванням і організацією заготівлі та переробки зерна. Відділ допомагав проведенню експортування перемолотих продуктів. 26 серпня делегація подала на розгляд до Міністра продовольчих справ проект торгового договору між Державним Хлібним Бюро та Радою Союзу мукомолів, який із схваленням було прийнято до Міністерства. Право на заключення договорів про торгівлю хлібом отримали члени Союзу мукомолів. Усі закупки та відходи складали власність Держави, а сама діяльність мукомолів поширювалась лише на райони, визначені Бюро. Створення спільного з представниками торгових і промислових сфер органу мало велике значення для підтримки політики гетьмана. Спільно із Радою Союзу мукомолів місцевими органами Бюро було закуплено в Волинській губ. - 1906750 пуд. зерна, в Катеринославській - 13440900 пуд., Подільській - 9550860 пуд., Полтавській - 7333.800 пуд., Таврійській - I0695149 пуд., Харківській - 3372216 пуд., Херсонській - 18088871 пуд., Чернігівській - 844957 пуд. Усього це складало - 7279714 пудів зерна. Хоча показники закупок хліба були значними, дійсний процент їх участі в торговому державному обігу був досить невеликим. У жовтні до споживачів дійшло лише 27498918 пуд. [6]. Цифри вражаючі, коли країна переживала хлібний голод. Крім іноземного втручання до «хлібної торгової кампанії», виконання планів ускладнювала нестача вагонів і нестабільна робота залізниць. Якщо Бюро замовляло 1200-1300 вагонів на добу, то цей наряд виконувався лише на 1/3 [23].

Нові труднощі виникли у вигляді антигетьманської агітації на селі, спрямовані на підрив державної політики [1]. Для того, щоб забезпечити успішне проведення заготовчих операцій, Бюро постійно вело роз'яснювальну роботу і вдавалось до заходів, з метою укріплення ще слабких товарних відносин і заохочення селян.

Висновки. Дотримуючись напрямку державного протекціонізму у найважливіших галузях виробництва і торгівлі, Українська Держава намагалася зберігати інтереси як заможних власників i дрібного селянства, так і інших груп споживачів. Кризова ситуація в торговельній галузі країни вимагала від уряду гетьмана П. Скоропадського виявлення максимуму енергії для відновлення еко- 
номічного потенціалу. Розбудова правових підвалин економічної політики держави знаходилась у стані формування. Основним джерелом права виступали нормативно-правові акти (закони і підзаконні акти). Політика монополізації потребувала пильної уваги і обережності в ії впровадженні. Уряд мав вчасно реагувати на змінення стану монополізованих підприємств і галузей і відповідно змінювати форми контролю і державно-правової організації.

\section{Список використаних джерел}

1. Ц Центральний державний архів вищих органів влади і управління України. - Ф.1061. - Оп.1. - Спр. 60. -Арк. 4.

2. Ц Центральний державний архів вищих органів влади і управління України. - Ф.1064. - Оп.1. - Спр. 6. -Арк. 3.

3. Центральний державний архів вищих органів влади і управління України. - Ф.1064. - Оп.1. - Спр. 6. - Арк. 140.

4. Центральний державний архів вищих органів влади і управління України. - Ф.1064. -Оп.1. - Спр. 13(а). Арк. 74.

5. Центральний державний архів вищих органів влади і управління України. - Ф.2198. -Оп.1. - Спр. 18. Арк. 1-43.

6. Центральний державний архів вищих органів влади і управління України. - Ф. 2198. - Оп.1. - Спр. 22. Арк. 1-59.

7. Державний Вісник. - 1918, 16 травня.

8. Державний Вісник. - 1918, 7 червня.

9. Державний Вісник. - 1918, 9 червня.

10. Державний Вісник. - 1918, 14 червня.

11. Державний Вісник. - 1918, 22 червня.

12. Державний Вісник. $-1918,5$ липня..

13. Державний Вісник. - 1918, 1 серпня.

14. Державний Вісник. - 1918, 4 вересня.

15. Держсавний Вісник. $-1918,13$ жовтня.

16. Державний Вісник. - 1918, 19 жовтня.

17. Голос Киева. - 1918, 31 мая.

18. Известия Союза Протофиса Украины. - 1918, 1 сентября.

19. Известия Союза Протофиса Украины. - 1918, 9 сентября.

20. Известия Союза Протофиса Украины. - 1918, 23 сентября.

21. Известия Союза Протофиса Украины. - 1918, 21 октября.

22. Известия Союза Протофиса Украины. - 1918, 27 октября.

23. Известия Союза Протофиса Украины. - 1918, 11 ноября.

24. Известия Союза Протофиса Украины. - 1918, 18 ноября.

\section{Referens}

1. Tsentralnyi derzhavnyi arkhiv vyshchykh orhaniv vlady i upravlinnia Ukrainy. - F.1061. - Op.1. - Spr. 60. - Ark. 4.

2. Tsentralnyi derzhavnyi arkhiv vyshchykh orhaniv vlady i upravlinnia Ukrainy. - F.1064. - Op.1. - Spr. 6. - Ark. 3.

3. Tsentralnyi derzhavnyi arkhiv vyshchykh orhaniv vlady i upravlinnia Ukrainy. - F.1064. - Op.1. - Spr. 6. - Ark. 140.

4. Tsentralnyi derzhavnyi arkhiv vyshchykh orhaniv vlady i upravlinnia Ukrainy. - F.1064. - Op.1. - Spr. 13(a). Ark. 74.

5. Tsentralnyi derzhavnyi arkhiv vyshchykh orhaniv vlady i upravlinnia Ukrainy. - F.2198. - Op.1. - Spr. 18. - Ark. 1-43.

6. Tsentralnyi derzhavnyi arkhiv vyshchykh orhaniv vlady i upravlinnia Ukrainy. - F. 2198. - Op.1. - Spr. 22. - Ark. 1-59.

7. Derzhavnyi Visnyk. - 1918, 16 travnia.

8. Derzhavnyi Visnyk. - 1918, 7 chervnia.

9. Derzhavnyi Visnyk. - 1918, 9 chervnia.

10. Derzhavnyi Visnyk. - 1918, 14 chervnia.

11. Derzhavnyi Visnyk. - 1918, 22 chervnia.

12. Derzhavnyi Visnyk. - 1918, 5 lypnia..

13. Derzhavnyi Visnyk. - 1918, 1 serpnia.

14. Derzhavnyi Visnyk. - 1918, 4 veresnia.

15. Derzhavnyi Visnyk. - 1918, 13 zhovtnia.

16. Derzhavnyi Visnyk. $-1918,19$ zhovtnia.

17. Holos Kyeva. - 1918, 31 maia.

18. Yzvestyia Soiuza Protofysa Ukrayny. - 1918, 1 sentiabria.

19. Yzvestyia Soiuza Protofysa Ukrayny. - 1918, 9 sentiabria. 
20. Yzvestyia Soiuza Protofysa Ukrayny. - 1918, 23 sentiabria.

21. Yzvestyia Soiuza Protofysa Ukrayny. - 1918, 21 oktiabria.

22. Yzvestyia Soiuza Protofysa Ukrayny. - 1918, 27 oktiabria.

23. Yzvestyia Soiuza Protofysa Ukrayny. - 1918, 11 noiabria.

24. Yzvestyia Soiuza Protofysa Ukrayny. - 1918, 18 noiabria.

Камаралі С. Є. Шевченко Д. А. Торговельна політика уряду Павла Скоропадського: історикоправовий моніторинг

Стаття присвячена дослідженню різних аспектів організаційно-правових основ діяльності уряду гетьмана П. Скоропадського в галузі внутрішньої торгівлі. Визначені пріоритетні вектори фінансово-економічної політики в період кризи державотворення, в складних умовах Брест-Литовських зобов'язань. 3 використанням широкого кола архівних матеріалів висвітлені етапи встановлення державної монополії на продаж зернової, цукрової та горілчаної продукції; подані матеріали активної співпраці міністерств Української Держави із представниками торговельно-промислових кіл; проаналізована діяльність «Відділу для виготовлення торгово-економічних договоріву», «Комітету для зовнішньої торгівлі», «Комісії з справ цукру», Особливого Торговельно-Фінансового відділу при Раді мукомолів, Державного Хлібного Бюро і «Товариства винокуренних заводчиків».

Ключові слова: Українська Держава, гетьман П. Скоропадський, економічна політика, торговельна політика, хлібна монополія, цукрова промисловість, горілчана промисловість.

Kamaraly S. Y. Shevchenko D. A. The trade policy of the government of P. Skoropadsky: historical and legal monitoring

The article is devoted to the study of various aspects of the organizational and legal foundations of Hetman P. Skoropadsky's government in the field of internal trade. Identify the priority vectors of financial and economic policy during the crisis of state formation, under the difficult conditions of the Brest-Litovsk commitments.Using a wide range of archival materials, the author outlines the stages of establishing a state monopoly for the sale of grain, sugar and vodka products; materials of active cooperation of the Ministries of the Ukrainian State with representatives of trade and industry are presented; The activities of the «Trade and Economic Contracts Division», "The Committee for Foreign Trade», «Sugar Commission», the Special Trade and Finance Department at the Council of Flour-mills, the State Bread Bureau and the Society of Distillers were analyzed.

Key words: Ukrainian state, Hetman P. Skoropadsky, economic policy, trade policy, grain monopoly, sugar industry, vodka industry.

DOI: 10.33.66.3/2524-017X-2019-10-132-137 